\title{
RUSSIANS IN THE REPUBLICS OF THE NORTH CAUCASUS: FRONTIERS OF GEO-DEMOGRAPHIC RETREAT (THE FIRST HALF OF THE 21st CENTURY) *
}

\section{SERGEI SUSHCHIY}

\begin{abstract}
The article analyzes the geo-demographic dynamics of the Russian population of the republics of the North Caucasus in the post-Soviet period, registering the pace of reduction for each republic and studying the central role of migration in this depopulation process. Currently, the Russian population of the North Caucasus has returned to the level of the mid-1930s. The Republics of Chechnya and Ingushetia have lost almost all of their Russian population, while Dagestan has lost a significant part of its, too. Although demographic losses in other republics of the region have not been so great, a rapid reduction in the number of Russians has become a steady trend of the entire North Caucasus. In order to determine the corridor of the most likely demographic dynamics of Russians in the region up until 2050, a series of calculations was carried out, establishing that by 2030 the number of Russians in the North Caucasus will be reduced to 690780 thousand people, and by mid-century - to 490-700 thousand. No less a threat will come from the deterioration of the age distribution of the local Russian population, which could lead to its demographic "collapse" in the period 2060-2070.
\end{abstract}

Key words: North Caucasus, Russian population, demographic dynamics and settlement, migration, assimilation processes.

\section{NEW FEATURES OF MIGRATION POLICY}

Russians, who account for more than $80 \%$ of the country's population, are the most numerous ethnic group of the Russian state. Therefore, their traditional presence in all macroregions of the country, as well as their active participation in the social life of these regions, is not surprising. Accordingly, a significant demographic indicator is the socio-demographic dynamics of the Russian population in the regions of the Russian Federation, including in national autonomies. The dynamics of the size (and proportion) of the local Russian population, the directions of its migration and the scale of its outflows are significant characteristics of the level of integration of the republics in the life cycles of the whole of Russia.

Therefore, the rapid shrinking of the Russian population of the North Caucasus in the postSoviet period is quite reasonably perceived by experts and Russian society in general as an alarming sign. The number of studies devoted to various aspects of this topic is quite large [Ataev 2013; Belozerov 2001; Denisova, Ulanov 2003; Dzadziev 2007; 2008; Kabuzan 1996; North Caucasus ... 2010]. However, a detailed analysis of the modern quantitative dynamics of the Russian population of the North Caucasus, as well as its geodemographic prospects, has not attracted sufficient attention from specialists.

SERGEI SUSHChIY (SS7707@mail.ru), InSTITUTE OF SOCIO-ECONOMIC AND HUMANITIES RESEARCH (SSC RAS), RUSSIA.

* The original article in Russian Was Published in DEMOgRaphic REVIEW IN 2016, 4(3): 115-140.

DOI: 10.17323/DEMREVIEW.V4I3.7319

THE WORK WAS CARRIED OUT WITHIN THE FRAMEWORK OF THE PROJECT "PROBLEMS OF DEMOGRAPHIC AND SOCIO-ECONOMIC DEVELOPMENT OF THE SOUTHERN MACROREGION (0260-2014-0004)" OF THE BASIC RESEARCH PROGRAM OF THE PRESIDIUM OF THE RAS. 
The outflow of Russians from the region is a process that began long before the collapse of the USSR. Already in the 1960s, migration of the Russian population from Dagestan was recorded (Table 1). However, in general, net migration of Russians remained positive throughout the region. But already in the next decade the situation changed dramatically: In the 1970s, almost the whole of the North Caucasus became a zone of negative net migration of Russians. This situation continued in the 1980s. The main outflow in the last two Soviet decades came from the two eastern republics of the region - Dagestan and Checheno-Ingushetia.

Table 1. Migration dynamics of the Russian population in the republics of the North Caucasus in the 1960-2000s, thousand people*

\begin{tabular}{l|r|r|r|r|r}
\hline \multirow{2}{*}{ Republics } & \multicolumn{5}{c}{ Periods } \\
\cline { 2 - 6 } & $1959-1970$ & $1970-1979$ & $1980-1989$ & $1989-2002$ & $2002-2010$ \\
\hline Adygea & $5-7$ & $-1-2$ & 0 & $7-8$ & $-5-6$ \\
Dagestan & $-25-30$ & -30 & $-31-33$ & -35 & $-8-9$ \\
Ingushetia & - & - & - & -20 & $-1-1.5$ \\
Kabardino-Balkaria & $30-35$ & $3-4$ & $-2-3$ & $-9-10$ & $-15-16$ \\
Karachaevo-Cherksessia & 0 & $-3-4$ & $6-7$ & -18 & $-11-12$ \\
North Ossetia & $2-3$ & $-9-10$ & $-18-20$ & -18 & $-4-5$ \\
Checheno-Ingushetia & 0 & $-45-50$ & $-55-57$ & - & $-248-250$ \\
Chechen Republic & - & - & - & $-2-3$ \\
All republics & $12-15$ & $-85-92$ & $-100-106$ & $-341-343$ & $-60-65$ \\
\hline
\end{tabular}

Note: * - Calculated by the author on the basis of data on the overall dynamics of the population of the Russian population and on the natural growth of Russians in the republics of the North Caucasus in the relevant periods.

The total migration loss of the region's Russian population in the 1970s-1980s came to about 200,000 people. Such a significant decline could not be compensated for by natural growth. The number of Russians in the North Caucasus, having reached its historic maximum (the first half of the 1970s), began to decline. During the period 1970-1979 it fell from 1,436,000 to $1,412,000$ people.

The rate of decline of the Russian population, which had increased gradually up to the end of the Soviet period, in the 1990s moved into high gear. In the first post-Soviet decade, about 340,000 Russians left the region. In some cases, migration, in fact, took the form of an ethnic exodus. It is hard to describe otherwise the events that took place in the Chechen Republic and Ingushetia in 1991-1993, when about 200,000 people left the republic, the bulk of whom were Russian. Another contribution to the reduction of the Russian population came from natural decline, which, by the beginning of the 21 st century was 5-6\% per year. As a result, by 2002 the number of Russians in the region had fallen below the one-million bar, returning to the level of the turn of the 1940s.

Russia's political and socio-economic stabilization at the start of the $21^{\text {st }}$ century made it possible to significantly reduce the outflow. However, Russian migration from the North Caucasus continues in the 2000s. In 2002-2010, the Russian population of the region according to official figures decreased by more than 100,000 people. Given that the size of the natural loss of Russians during this period was about 4\% (about 40,000 people), the remaining 60,000 people of the demographic decline were accounted for by migration, the intensity of which in a number of republics has even increased. 
In total, from 1989 to 2010 the Russian population of the North Caucasus shrank by more than 1.5 times. Even more noticeable were the percentage losses: the share of Russians in the region's population, which had reached $44 \%$ at the turn of the 1960 s, fell to $27 \%$ by the end of the Soviet period, and in 2010 was only $12 \%$.

The reasons for the demographic "collapse" of these republics' Russian communities are well known. Repeatedly voiced in the expert literature, they include: an economic factor (the deindustrialization of the North Caucasus and the loss by the Russian population of its main production niches); the complex ethnicization of the social life of the republics (a significant dominance of indigenous peoples in power structures and in all prestigious hierarchies); and the legal precariousness of the Russian population and presence of inter-ethnic tensions.

It is also obvious that the "Russian question" is not independent, but represents only one of a wide set of problems, a solution to which is possible only through the successful implementation of a project of systemic transformation of the North Caucasus - a serious modernization of its political, socio-economic, and cultural life, which in turn presupposes corresponding changes in the social realities of Russia as a whole. However, Russian authorities today prefer not to undertake such a monumental task, meaning there is every reason to believe that the geodemographic dynamics of the Russian population in the North Caucasus will continue to be determined by factors contributing to its further quantitative reduction and spatial compression.

This process, which represents a complex derivative of ethno-political, socio-economic and sociocultural factors that determine the scale of the outflow of Russians, will differ significantly in different republics. However, not only migration, but also indicators of the natural dynamics of the Russians can vary within a fairly wide range. The ratio of fertility to mortality will depend on the socio-economic success of both the entire Russian Federation and each specific region, as well as on the demographic policy of the Russian government, the scale of the fertility promotion programs, the level of development of the health care system, the diffusion of a healthy lifestyle, and the effectiveness of the state (and society) in combatting alcoholism, smoking and drug addiction.

This article attempts to assess the possible changes in the size of the Russian population in the North Caucasus republics using the component method with different options for changing the parameters of the natural reproduction of Russians in this region. As the main parameters for calculating a pessimistic (negative) scenario, we extrapolated to the mid-term (up to 2025-2030) and long-term (up to 2050) indicators for fertility, mortality, age-specific survival rates, and the life expectancy of the population of Russia in 2010, assuming a slight improvement in each decade of the analyzed period.

In this scenario, the average life expectancy for both men and women in Russia for the period 2010-2050 should grow by about four years (from 63 to 67 and from 74.8 to 79 , respectively), while the survival rates for different age groups of the Russian population (i.e. primarily Russians, who account for about $80 \%$ of the population of the Russian Federation) would, by the middle of the century, improve by $10-20 \%$ compared to 2010 indicators.

To calculate the optimistic scenario, we proceeded from the assumption that the main demographic indicators of the population of the country and of Russians during the period under 
review will improve significantly. It is assumed that by the middle of the century life expectancy in the Russian Federation, having increased by 13-14 years relative to 2010, will be comparable with the current population of the countries of Western Europe and North America.

As a result, if, under the negative scenario of natural dynamics, Russians in the North Caucasus for the period 2010-2050 will have lost about $23-26 \%$ of their numbers, then the unfolding of the optimistic scenario makes it possible to reduce these losses to 14-16\%.

Thus, the combination of different scenarios of natural and migratory dynamics forms a certain corridor of likely demographic opportunities for Russians in the republics of the North Caucasus in the medium and longer term. The combination of a positive scenario of natural dynamics and the maximum possible reduction in outflows (for each republic its real value was selected) set the upper limit of this corridor. The negative scenario of natural decline, combined with the preservation of a significant outflow, determined the lower level of the possible demographic dynamics of Russians.

\section{THE ChECHEN REPUBLIC}

The 2002 census recorded only 40,600 Russians in Chechnya, of whom about 24,000 belonged to federal armed forces. Thus, the civilian population (the remains of the Russian "old-timers") was no more than 16,000 people. Most of them lived in a small number of settlements in two of the Nadterechny districts of the republic (Naursky and Shelkovsky), as well as in Grozny itself. Thus, the overwhelming majority of settlements in Chechnya, including very large ones, had practically no Russian population at the beginning of the 21 st century.

By 2010, the Russian population of the republic was reduced to 24,000 people, primarily due to the reduction of the military presence, which, however, still represented a significant number of Russians (about 11,000). Thus, the actual Russian community (the civilian population) was about 13,000 people, having decreased by about $20 \%$ compared to 2002 .

The age composition of local Russians, minus the peaks formed by the "feds" (contract soldiers and officers), reveals a fairly even contour (a "rectangle") with an increased proportion of middle-aged and older people (Figure 1). However, this form of the age pyramid does not suggest a rapid natural shrinking of the diaspora in the coming decades. 


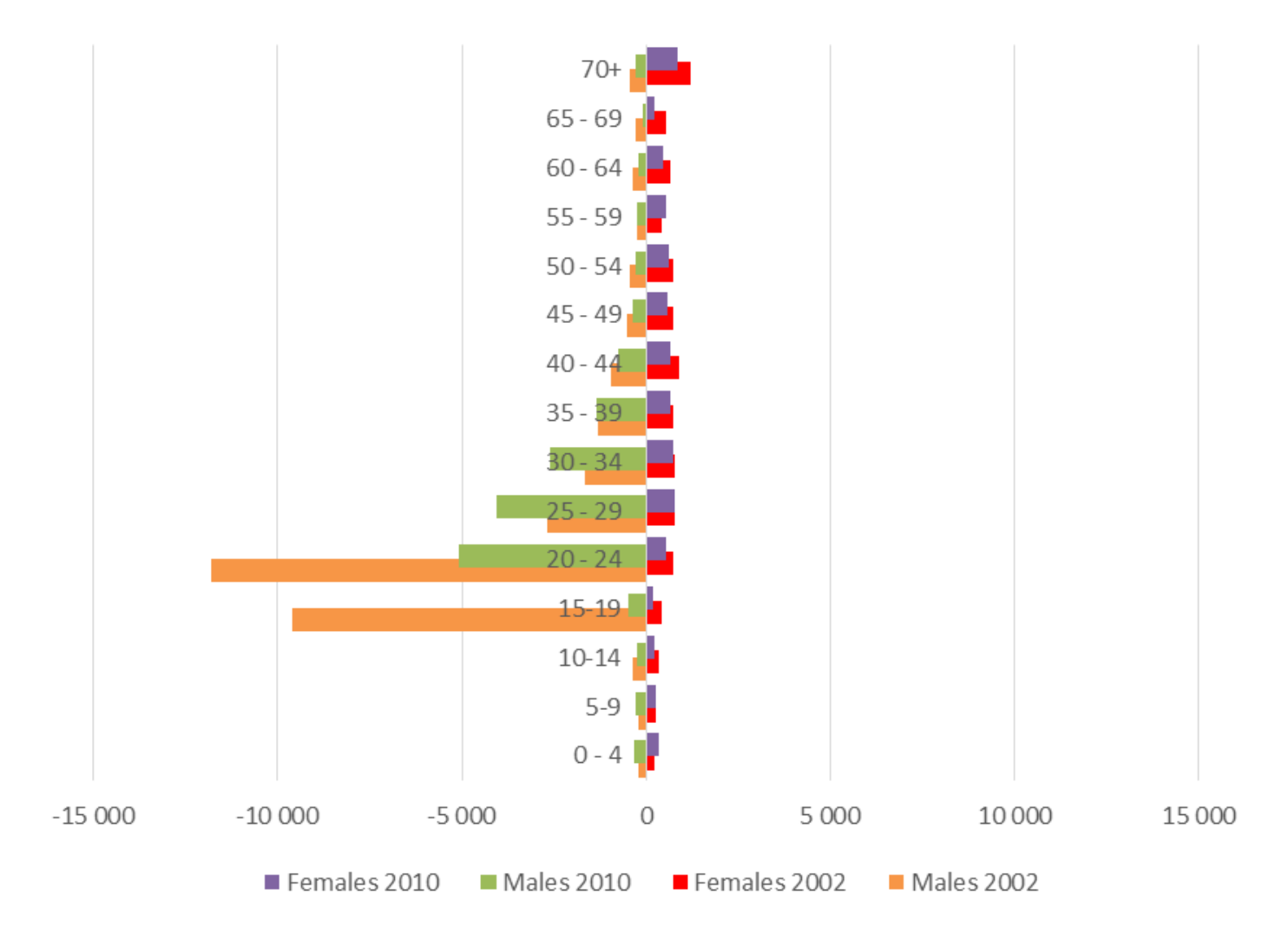

Figure 1. Age composition of the Russian population of the Chechen Republic, 2002-2010, people

In other words, if the problem of the outflow of Russians from the republic were solved, even such a small diaspora could last for a long time, including in the years 2030-2040 about 1012,000 people (that is, a little less than at present). However, further migration of Russians from the republic is almost inevitable. In addition, in order for the quantitative conservation scenario to work, the community needs to maintain at least the level of fertility characteristic of the entire Russian population of Russia. Yet, according to the 2010 census, for one Russian woman at active reproductive age (20-39 years) in the Chechen Republic there were 0.76 children under the age of 20 years $^{1}$, while the Russian national rate was 1.28 children.

The main reason for the extremely low level is not in the actual small number of local Russian women, but in inter-ethnic (Russian-Chechen) marriages. The bulk of children in such mixed families are recorded by the census as having the father's nationality, as being part of the indigenous people. Such a principle of national self-determination of mixed offspring of interethnic families, in this case, fully corresponds to the social realities of the republic. In the conditions of a traditional society with the absolute dominance of the father-husband, almost all the children born in such marriages become representatives of the Chechen people in their psychosocial and sociocultural specifics.

\footnotetext{
${ }^{1}$ Not including a certain number of representatives of the federal forces - young men aged 18-19. 


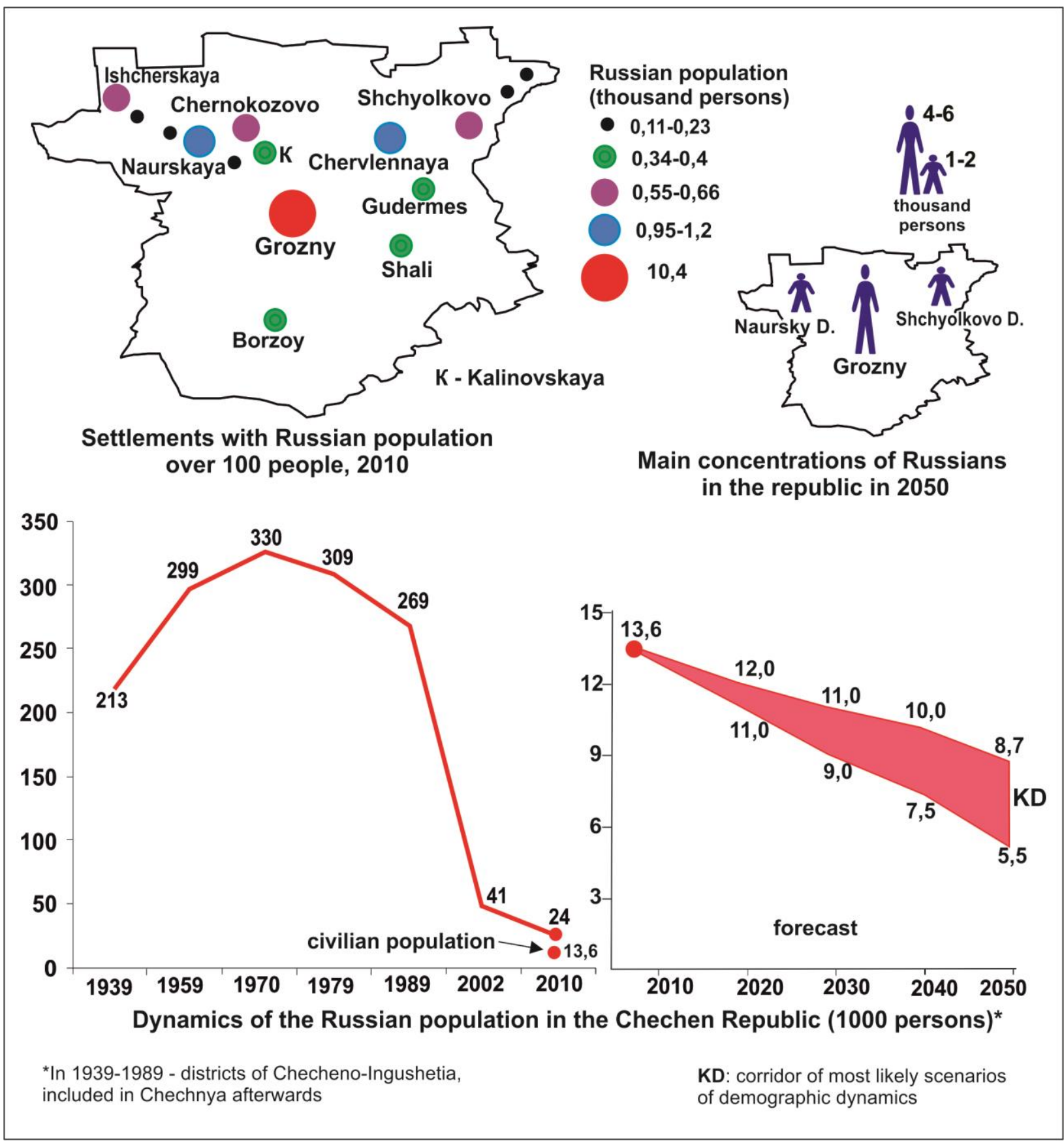

Figure 2. Russians in the Chechen Republic, 1939-2050

Based on the existing indicator of the average number of children, it can be assumed that up to $30 \%$ (possibly more) of Russian women of active childbearing age currently living in the republic have an "indigenous" husband. Consequently, a significant proportion of potential mothers are excluded from the demographic reproduction of the Russian community of Chechnya.

Meanwhile, the total number of Russian women of childbearing age in the republic began rapidly declining in the middle of the current decade: those now entering adulthood are the not numerous natives of the late twentieth century. Even without taking into account possible migration, the number of Russian women aged 20-39 in Chechnya by 2020 will be reduced to 1,700 (from 2,700 in 2010), and in 2030 will be only one thousand. As a result, all future 
generations of Russians in the republic will inevitably be several times smaller than groups of middle age or older.

The most probable quantitative range of the demographic dynamics of the Russian community of Chechnya is shown in Figure 2. At the same time, the possible work of the assimilation factor is not fully taken into account in the chart, and therefore a more negative demographic scenario is not ruled out.

However, it is also necessary to take into account the fact that for "representative" purposes of the Chechen authorities it is advantageous to have at least some number of settlements with a distinct presence of Russians. To do this, it would be prudent to support and preserve the remaining centers, where, if necessary, it would be possible to bring high-ranking guests from the federal center. This practical consideration may somewhat prolong the life of the Russian community concentrated by the middle of the century in a number of settlements in northern Chechnya and, perhaps, in Grozny.

\section{INGUSHETIA}

The "Russian question" in Ingushetia repeats, in its geodemographic aspect, the situation of neighboring Chechnya, with the difference that in the areas of Soviet Chechen-Ingushetia, subsequently included in Ingushetia, the Russian population was initially limited quantitatively. At the turn of the 1990s, it numbered about 25,000 people. About 20,000 of them left the republic in the first post-Soviet decade.

The 2002 census recorded 5,500 Russians in Ingushetia. However, an analysis of their age composition makes it possible to classify about a thousand people as belonging to the federal forces. Thus, the republic's Russian community might have numbered approximately 4,500 people at that time. At the same time, a significant part of it was compactly concentrated in several stanitsas (Cossack villages), mainly in Troitskaya, Ordzhonikidzevskaya, Nesterovskaya, and Voznesenskaya.

The 2010 census recorded a reduction in the Russian community to 3,000 persons, meaning that it contracted by about a third during the "aughts". Given the limited scale of natural decline, this was mainly the result of the continuing intensive migration outflow, which for 2003-2010 could have been between 1,000 and 1,500 people. Moreover, since the beginning of 2005 the target program "Return and resettlement of the Russian-speaking population" had been operating in the republic. Its complete absence of results was clear evidence that the "de-Russification" of Ingushetia was a fait accompli. 


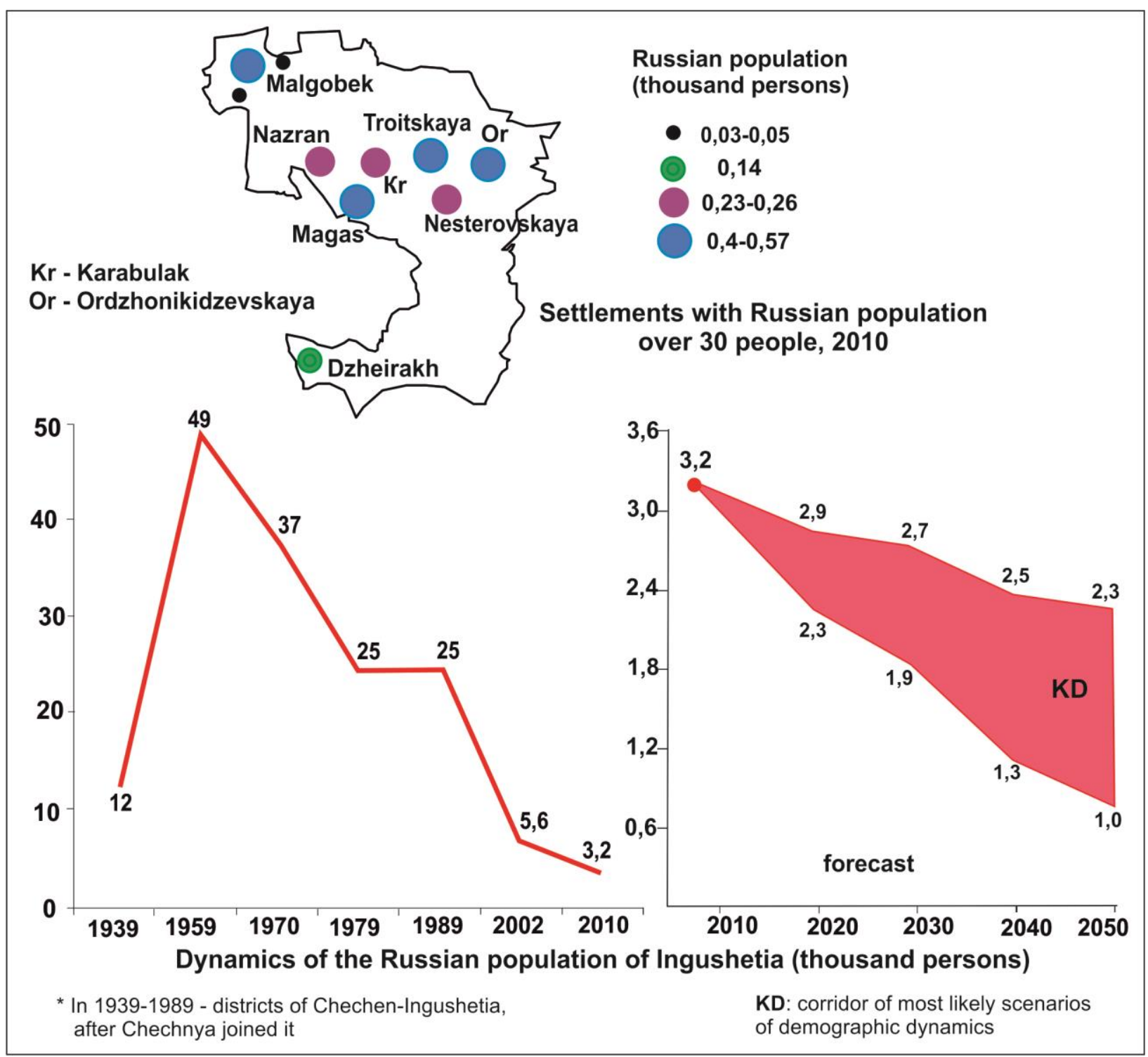

Figure 3. Russians in Ingushetia, 1939-2050

Each following census of the Russian population would record a further reduction of the local Russian community, primarily due to further outflow and assimilation, rather than natural decline. According to the 2010 census, Russians in the republic had only 0.88 children per active woman of childbearing age. The reason for such a small number of children is the same as in neighboring Chechnya. Corresponding calculations suggest that currently in Ingushetia about 20$25 \%$ of Russian women of reproductive age are married to Ingush, i.e. "help" the demographics of the indigenous people. Rapid quantitative reduction of the community in such a situation is inevitable even without taking into account migration (Figure 3). At the same time, the lower edge of the quantitative range shown on the map is calculated for a smaller outflow of Russians from the republic than existed in the first decade of the $21^{\text {st }}$ century. But the preservation of migration at the level of the 2000s, with the participation of the assimilation factor and natural decline, will already by 2030 have reduced the local Russian community to several hundred people. In this case, by the middle of the century, the Russian population of the republic, minus the security forces there on duty, will be represented by a small group of old-timers and a tiny number of random people brought to Ingushetia by the whims of life circumstances. 


\section{DAGESTAN}

The most significant progress in reducing the number of Russians has been made in the third republic of the North-Eastern Caucasus, Dagestan. This process has been underway for more than half a century, but accelerated greatly in the post-Soviet decades. At its peak, in the mid- and late 1990s, as many as 4,000-6,000 Russians left the republic annually. By 2010, this figure was reduced to $1,000-1,500$ people.

In the first years of the 21st century, the outflow was reduced to 1,500-2000 people, and in 2003-2005 came to 1,200-1,500 annually [Dagestan-2005 ...: 15]. In the mid-2000s was launched the "North" program, aimed at bringing back the Russian population. However, in the second half of the "aughts" migration outflow of Russians from Dagestan was about a thousand people a year and significantly exceeded their natural decline.

The 2010 census recorded 104,000 Russians (101,000 not including military units) in the republic. Thus, over the period 2002-2010 the community decreased by 14,000 people, of whom no more than 4,000-5,000 were the result of natural decline.

Analyzing the possible prospects of the Russian community, it is necessary to take into account the geographical narrowness of its modern presence in the republic. Most of Dagestan by now has practically no Russian population. In half of the country's rural areas, groups of Russians make up no more than 20-30 people (tenths, and sometimes hundredths of a percent of the population). Out of almost 1,500 settlements of the republic in 2010, Russians were completely absent or had a minimum number (1-2 people) in 1,124 of them (3/4 of the settlement network of the republic). If you take into account the settlements in which there were only a few Russians (310), the share of "derussified" settlements rises to $90 \%$.

About $60 \%$ of the republic's Russians are concentrated in the metropolitan agglomeration of Makhachkala and Kaspiisk and in Kizlyar. If we include Derbent, Khasavyurt and the two northern regions of Kizlyar and Tarumovsky, this share grows to $80 \%$.

At the same time, the modern age "pyramid" of Russian Dagestan (Figure 4) has the form of a rectangle, i.e. almost does not differ from the federal one and does not suggest any rapid demographic shrinkage in the coming decades. But two factors (as in the two Vainakh republics) - migration and assimilation - will significantly accelerate its reduction.

The low fertility of Russian women in Dagestan (0.98 children per woman aged 20-39) recorded by demographic statistics is not as pronounced as in the Chechen Republic and Ingushetia. But it also shows that currently about $15-20 \%$ of local Russian women are in interethnic marriages. 


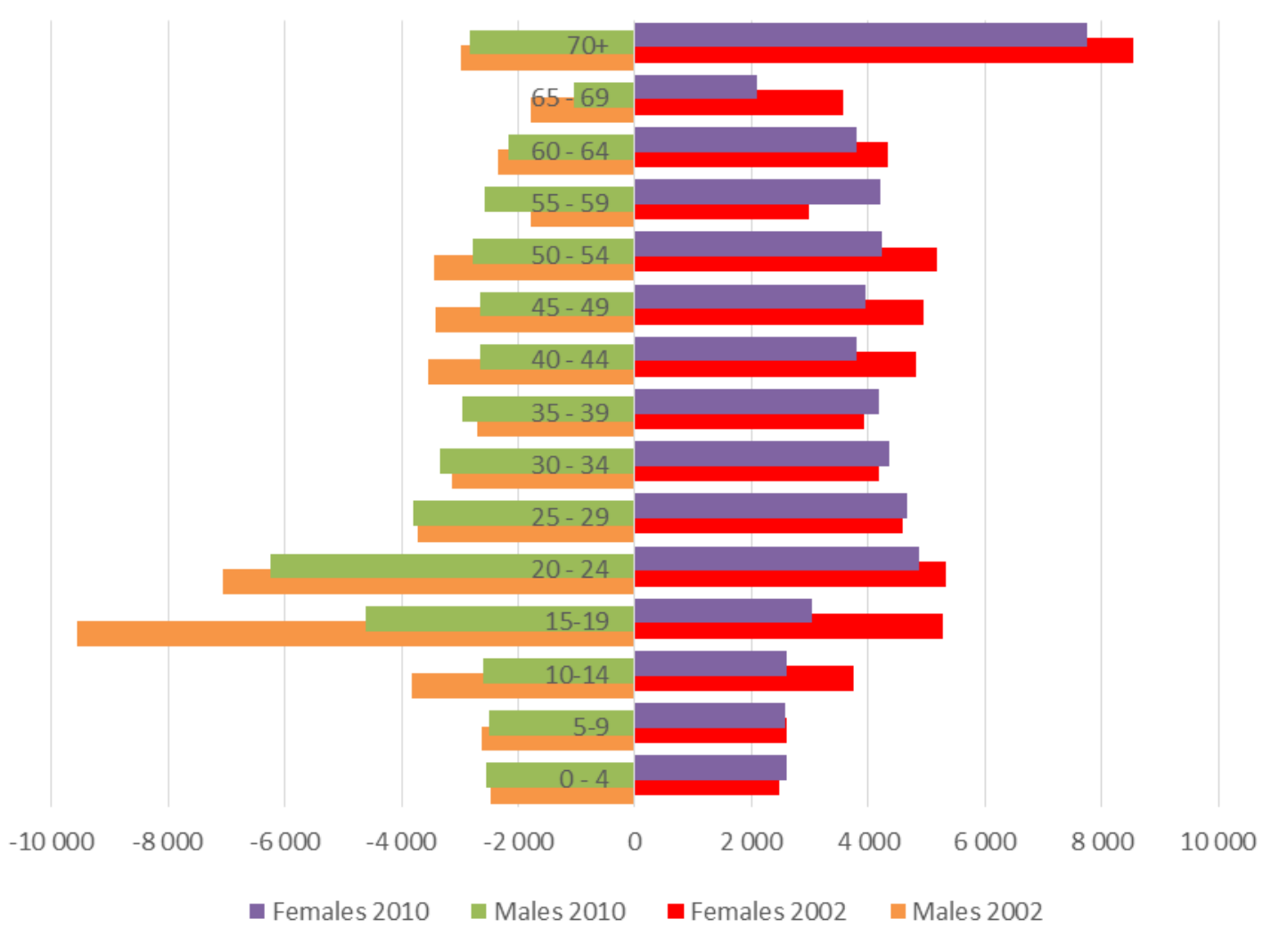

\section{Figure 4. Age composition of the Russian population of Dagestan, 2002-2010, people}

An important role in the downward demographic dynamics of local Russians will obviously be played also by migration. The complex ethno-political and socio-economic situation in the republic, just like the existing migration tendency, practically predetermines the further outflow of Russians from the republic. Only its scale is in question. Given the long-term persistence of annual migration rates at the current level (up to $1 \%$ of their total number) and the negative scenario of natural dynamics (the lower bar of the corridor of demographic opportunities), the number of Russians in Dagestan may drop to 75,000 by 2030, and by mid-century will be less than 50,000 (Figure 5).

But even the unfolding of the scenario of minimal natural loss with a threefold decrease in the outflow rate (about $0.3 \%$ per year) will lead to a reduction in the Russian population of Dagestan by 2050 to 75,000 people.

Thus, the range of likely demographic dynamics of the Russian population of Dagestan cannot be called catastrophic, but it does not inspire optimism either. Russians, who at the turn of the 1960s represented more than one fifth of the population of the republic, by 2040-2050 will have become once and for all a small ethnic group (1.5-2.0\% of the inhabitants of Dagestan), having fallen from second place (1959) to eighth or ninth in the demographic ranking of the peoples of the republic. The territory of Russian resettlement in the middle of the $21^{\text {st }}$ century will essentially be limited to Makhachkala, Kizlyar and two northern districts of Dagestan. 


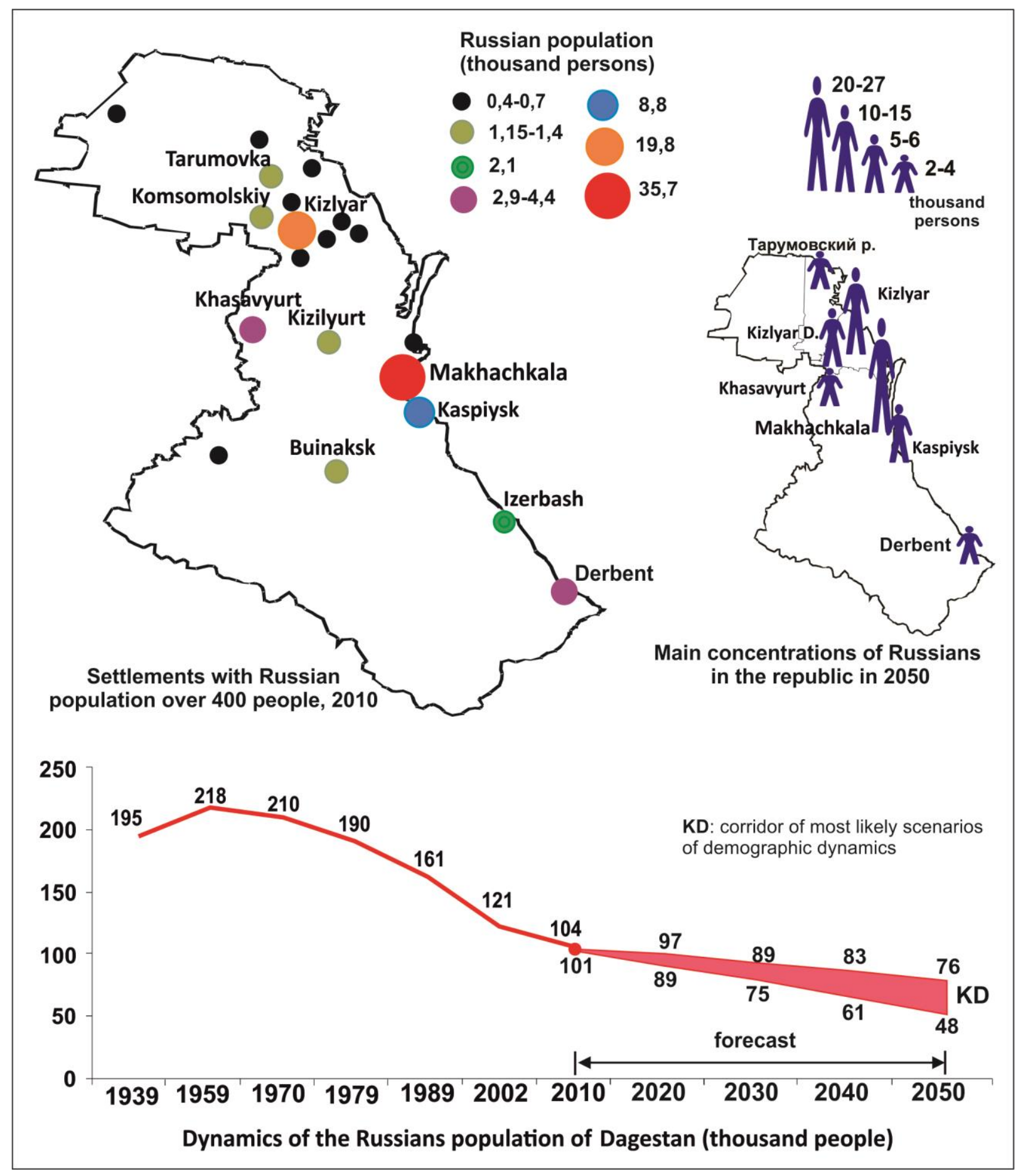

Figure 5. Russians in Dagestan, 1939-2050

\section{NORTH OSSETIA}

The "Russian question" in North Ossetia is not as acute as in the North-Eastern Caucasus. There are a lot of Russians here, and they continue to be the second largest ethnic group in the republic. However, their demographic decline remained a stable trend throughout the post-Soviet period. In the 1990s, the annual outflow, according to A.B. Dzadziev, remained at the level of 800-1,000 people, and the overall reduction of the Russian population in the republic in 1989-2002 (by 24 
thousand people) was equally conditioned by natural decline and migration [Dzadziev 2008: 133137].

But there is every reason to believe that the real outflow of Russians was even greater. The 2002 census recorded 165,000 Russians in the republic. However, an analysis of their age composition allows the attribution of about 11,500 people to the federal forces. Thus, the "civilian" Russian community of North Ossetia at the beginning of the $21^{\text {st }}$ century numbered $153-154,000$ people, and its real reduction for the period 1989-2002 could be about 34-35,000 people, indicating a much higher rate of migration, which at the peak of Russia's systemic crisis (the early through the mid-1990s) could have reached 2,000 people a year, and by the turn of the new century should have shrunk to an annual 1,000-1,500.

The outflow of the Russian population at this time was almost ubiquitous. In droves Russians left Vladikavkaz and other cities, as well as rural areas. The trend continued into the first decade of the $21^{\text {st }}$ century. According to the 2010 census, there were more than 147,000 Russians left in the republic, of whom about 4,500 belonged to the federal forces. Thus, the old-timer population was about 143,000 people, having declined since the previous census by 10,000-11,000 people. About $6,000-7,000$ of this number could be due to natural decline, about $4,000-5000$ to migration (the average annual level is 500-600 people). Thus, the outflow of Russians significantly decreased in comparison with the first post-Soviet decade, but remained a stable trend, significantly accelerating the demographic contraction of the local Russian community.

Analyzing the reasons for the migration of the Russian population from the republic, researchers tend to focus on economic factors. Given the high level of socio-cultural modernization and the Orthodoxy of a large part of the indigenous population of North Ossetia-Alania, there are at first glance no other serious reasons for an intensive outflow. However, the systemic ethnicization of the republic's society makes itself felt in full in post-Soviet Ossetia. And sociological surveys record a clear understanding by local Russians of their lack of social prospects (their "second-rateness"), which does not allow them to compete on equal terms with the indigenous population for status positions [North Caucasus ... 2010: 24].

The steady outflow of Russians from the republic testifies to the fact that they have not yet fully accepted their increasingly marginalized social status. More precisely, obvious age differences are visible: if the older generation has somehow been reconciled to its loss of status, a significant part of young people (about a third) are hoping to leave for "big" Russia. It is young people that make up a significant part of the modern Russian migration from North Ossetia.

Thus, the dynamics of the Russian population in the republic, both in the near (until 2020) and long term, are more likely to be determined by the double "work" of natural loss and migration. And the existing age composition of the Russian community indicates that in the current decade natural decline may play a more significant role in its demographic contraction. According to the 2010 census, in North Ossetia the oldest age group (people 70 and older) represented $12.6 \%$ of all Russians, and 23\% including those aged 60-69 (Figure 6). For Russia as a whole these figures were 10.4 and $19 \%$, respectively.

Meanwhile, the small generations of those born in the 1990s are now entering childbearing age. Suffice it to say that in the republic the number of Russian women of active reproductive age 
(20-39 years) will decrease from 22,200 in 2010 to 18,300 by 2020 , and in 2030 will be only 14,600 (and this without taking into account the migration factor). With such a significant reduction in the number of potential "moms", it is almost impossible to count on fertility, which can completely compensate for the natural decline in a population. However, if we assume that for one Russian woman of reproductive age in the country in the 2020-2030s there will be about 1.71.8 births, then the community, without taking into account the migration factor, may decline very slowly in the coming decades.

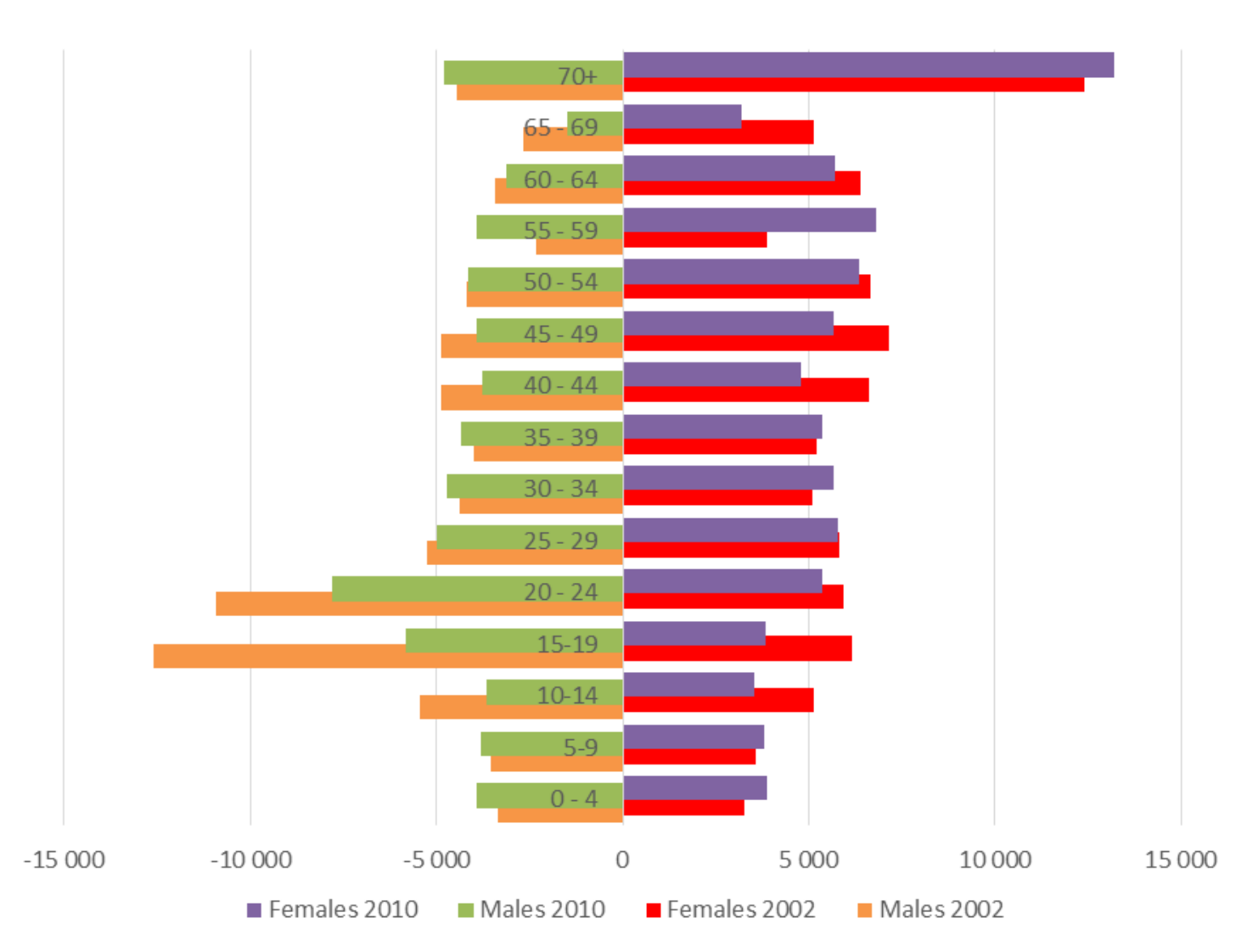

Figure 6. Age composition of the Russian population of North Ossetia, 2002-2010

It is significant that the ratio of children to women of reproductive age among Russians in the republic coincides with the indicator for Russia as a whole - evidence that the assimilation factor, so clearly recorded in the republics of the North-Eastern Caucasus, does not play a significant role in the demographic dynamics of the Russian population of North Ossetia. A common religion and similar levels of sociocultural modernization have substantially smoothed out the effects of this factor (that is, the mixed offspring of Russian-Ossetian marriages have become more evenly distributed between the two ethnic groups).

But there is still the migration factor. It is very likely that the outflow will continue for the foreseeable future. If its current scale remains unchanged, the Russian community could lose several thousand people every decade and, by the middle of the century, number fewer than 100,000 people (Figure 7). 


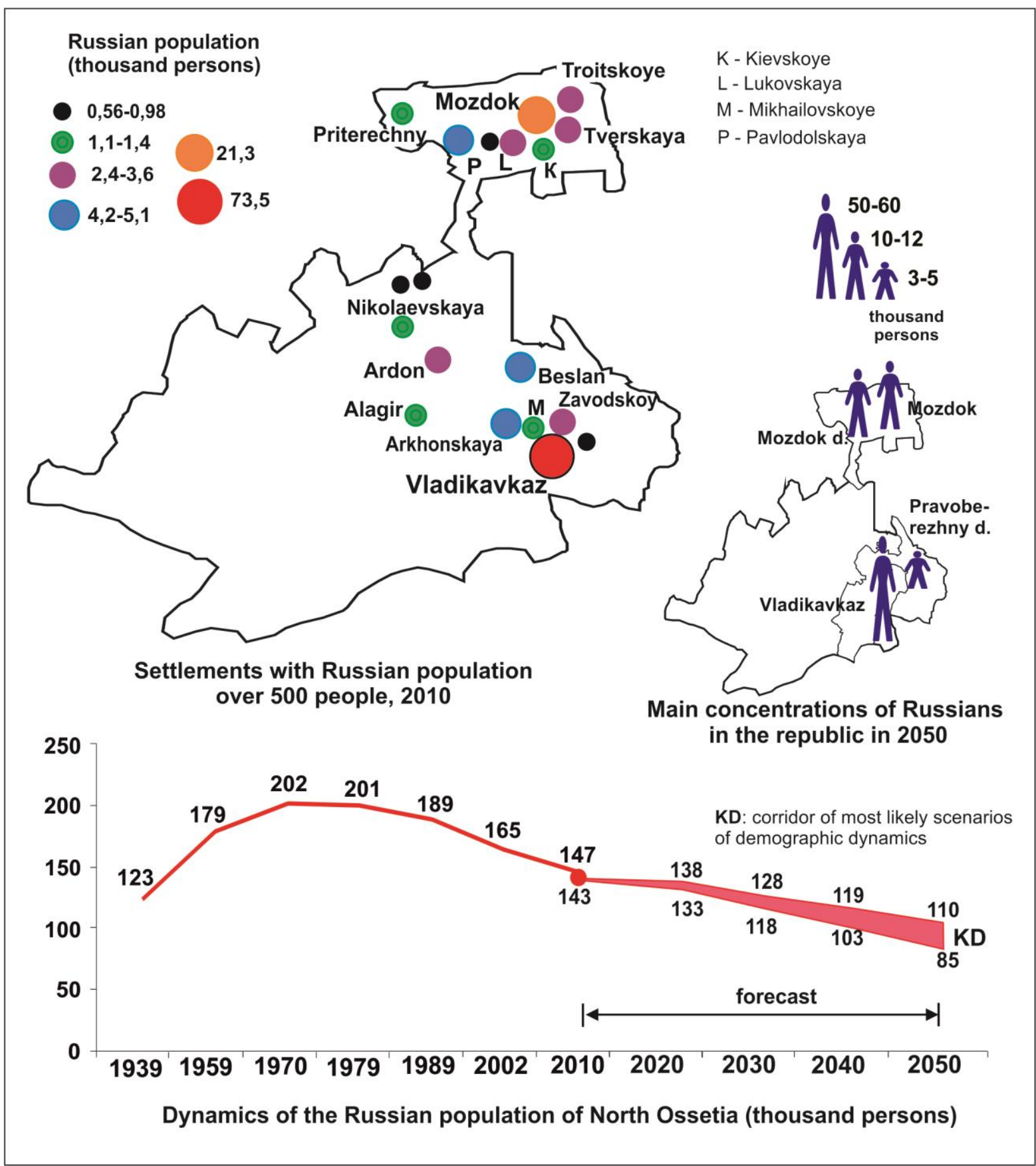

Figure 7. Russians in North Ossetia, 1939-2050

What matters, however, is not only the quantitative scale of the outflow, but also the deterioration in the age composition of the remaining Russians. The role of this indicator in the demographic depopulation of the Russian community over the next 15-25 years may be invisible for now. But after this period, the consequences could be almost catastrophic: in the middle of the century, the number of Russians may begin to "melt" at a rate of 3-4\% per year. However, this scenario assumes not only a sustained outflow, but also a sustained migration loss of a notable share of local Russian youth.

Currently, the geography of the Russian population in the republic is mainly limited to Vladikavkaz and Mozdok with the Mozdok region. In total, these two centers and the region 
account for more than $80 \%$ of all local Russians. In 71 settlements (almost $38 \%$ of the republic's entire settlement network), there are no Russians or their number is minimal (1-2 people). And if we include those settlements where the number of Russians is only 3-10 people, half of the resettlement system is essentially devoid of a Russian ethno-cultural presence (North Ossetia tends toward the deeply "derussified" Northeast Caucasus in this regard). And in the long term, the geography of Russians in the republic will continue to shrink, becoming more and more limited to the capital and the Mozdok region.

\section{KABARDINO-BALKARIA}

Back in the early 1970s, the Russian population accounted for $37 \%$ of the republic's population and, only slightly inferior in number to the Kabardians, continued to grow until the end of the Soviet period (240,000 in 1989).

The 2002 census recorded 226,200 Russians in Kabardino-Balkaria. Consequently, for the period 1989-2002 its number must have shrunk by only 14,000 people, of whom, according to A.B. Dzadziev, 12,000 were from natural decline and only 2,000 from migration [Dzadziev 2008: 131]. However, in another publication he gives quite different figures, asserting that in 1989-1998 alone about 7,700 Russians left the republic [Dzadziev 2007: 57]. In fact, this discrepancy may mean that the results of the 2002 census in Kabardino-Balkaria overstated not only the number of indigenous persons, but of Russians also.

There is every reason to believe that the total migration loss of the Russian population in 1989 - 2002 could come to about 10,000 people. Consequently, the number of Russians in the republic in 2002 was about 220,000 (about 218,000-219,000 without the military forces).

This assumption is partly confirmed by the further dynamics of the Russian community. According to the 2010 census, the number of Russians in the republic was 193,000-34,000 fewer than in 2002. If we proceed from these figures, we will have to acknowledge a significant increase in the migration outflow of Russians from the republic in the 2000s. Considering the size of the natural decline (about 9,000-11,000 people), about 23,000-25,000 people must have migrated in 2002-2010 (about 3,000 annually). In other words, the intensity of the outflow increased several times in comparison with the first post-Soviet decade. This could hardly be true.

But there is no doubt that the migration losses of Russians in the 2000s were indeed great. According to Kabardino-Balkaria's Migration Service, in 2005-2007 they came to about 2,000 people each year. Accordingly, for the entire intercensal period the outflow could amount to about $15,000-16,000$.

So, the population decline of the Russian community was more even than follows from the official results of the post-Soviet censuses (21,000-22,000 for 1989-2002, 25,000-26,000 for 20022010). But this result does not negate the main conclusion: on the whole, the republic that had successfully made it through the 1990s became, in the aughts, one of the leading regions in terms of the outflow of Russians from the North Caucasus. 


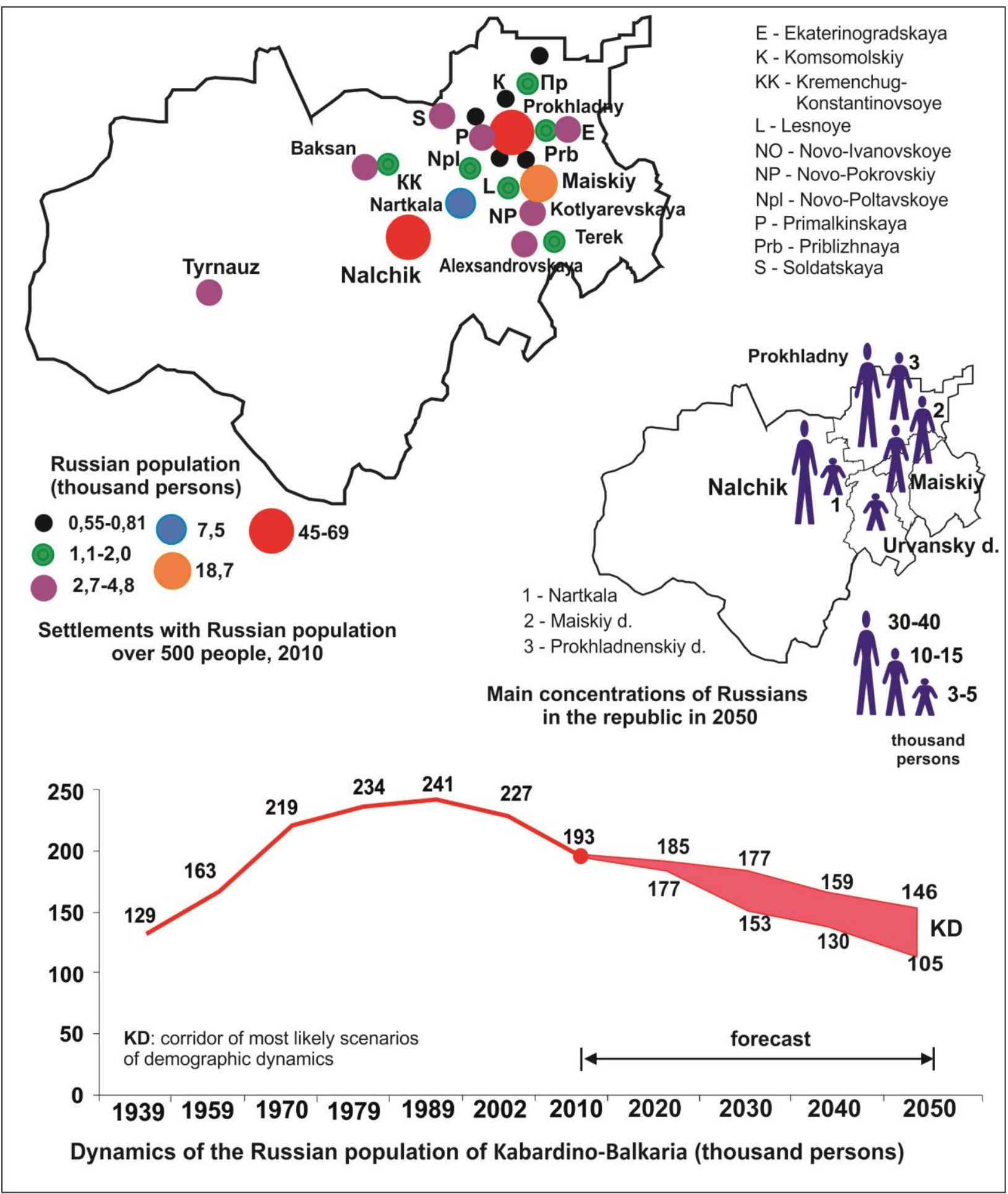

Figure 8. Russians in Kabardino-Balkaria, 1939-2050

Migration in the 2000s accounts for $60-70 \%$ of the demographic decline of the local Russian population. Moreover, it was young people who left the republic most intensely (as in North Ossetia). A calculation of the natural dynamics of the Russian community in the 2000s, taking into account the survival rate of different age groups, makes it possible to determine their migration losses. Among those in their twenties (20-29 years), the outflow was about 3,500 people, while for those in their thirties (30-39 years) it was over 8,000. In other words, Russian migration was primarily composed of young and middle-aged persons. 
Should this trend continue, the future age structure will have a large proportion of elderly people. The full negative impact of such a transformation of the republic's Russian community on its demographic dynamics may begin to be felt only in the second third of the century. But the current outline of the age pyramid already suggests a noticeable increase in natural losses in the second half of the current decade, when the representatives of the largest group of the republic's Russians, people aged 70 years and over, start to disappear en masse. In 2010, they accounted for $12.4 \%$ of the Russian population of Kabardino-Balkaria.

However, as already noted, migration plays a central role in the demographic compression of the republic's Russians. Its continuation in the coming decades at the level of $1 \%$ (up to 2000 people a year) could lead to the collapse of the Russian community by the middle of the $21^{\text {st }}$ century. However, the probability of such a demographic scenario is close to zero; more likely is a reduction of the outflow. With a decrease in its annual outflow rate to $0.7 \%$ and a negative scenario of natural dynamics, the number of Russians in Kabardino-Balkaria may drop to the 1,000 mark by the middle of the century (Figure 8).

A positive development of natural dynamics, along with migration at $0.3 \%$ per year, will allow the Russian community in 2050 to maintain its population at the level of 145-150 thousand people. In this case, despite shrinking significantly in number and share, Russians will still be in second place in the demographic ranking of the peoples of the republic, outstripping the Balkars.

The geography of local Russians will retain its basic contours under any demographic scenario. Already at the present time it is very narrow, with $90 \%$ of all the republic's Russians concentrated in Nalchik and two northeastern regions (Prokhladnensky and Maisky), occupying only one sixth of the territory of Kabardino-Balkaria. These regions and the republic's capital will also remain the main centers of the Russian population in the middle of the $21^{\text {st }}$ century.

\section{KARACHAEVO-CHERKESSIA}

During the second half of the twentieth century, the Russians were the largest ethnic group of Karachaevo-Cherkessia. Although their share in the population has been declining since 1959, the total number continued to grow until the end of the 1980s. Back in 2002, Russians accounted for more than a third of the population of the republic. At the same time, in terms of the rate of outflow of Russians in 1989-2002, the republic lagged behind only Chechnya and Dagestan - about 18,000 people (about 1,500 per year).

The socio-economic stabilization of the 2000s did not affect the intensity of this migration. Expert estimation of Russian migration losses for 2002-2010 gives a figure of 11-12 thousand people (the same 1,500 per year). And taking into account natural decline, the total demographic losses of the republic's Russians in this period were 17-18 thousand people.

All the more surprising therefore were the data of the 2010 census, according to which the number of Russians in the republic was 150,000 , i.e. had grown by a thousand people. Obviously, this figure has a weak relation to reality, as the real number of Russians in the republic can be only about 130,000 , some $80 \%$ of whom are currently concentrated in Cherkessk in the two western 
regions of Zelenchuk and Urupk (Figure 9) - that is , as in all other republics, the Russian population is distributed on the territory of Karachaevo-Cherkessia very unevenly.

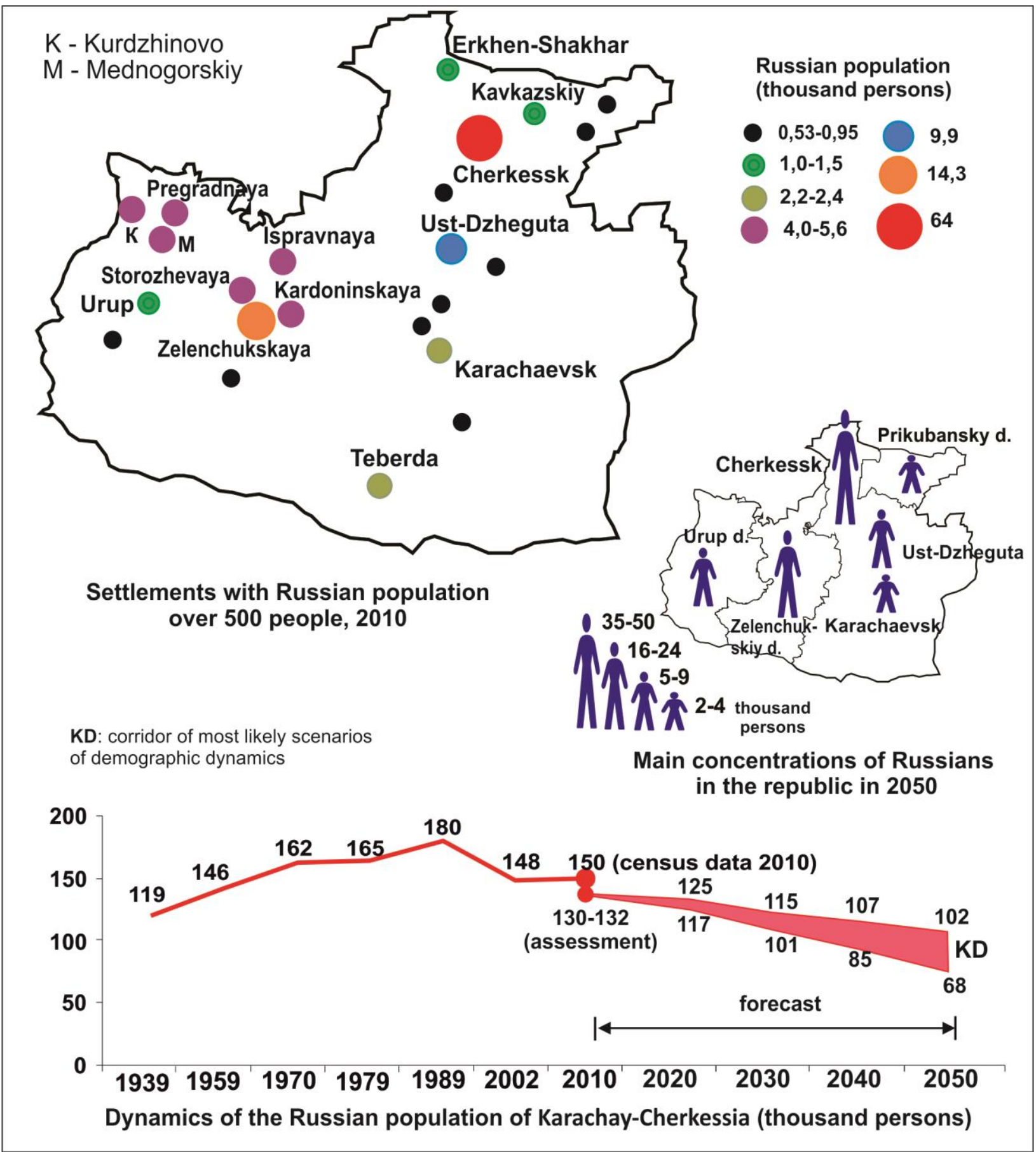

Figure 9. Russians in Karachaevo-Cherkessia, 1939-2050

The overcounting done in 2010 makes forecasting much harder. Moreover, it is hardly possible to check the results with those of the next censuses, since these future results will most likely become "hostages" of the falsifications that have already occurred. Indeed, given the steady decline in the local Russian population, the 2020 census, if conducted without overcounting, should give a figure that is substantially inferior to that of 2010 (since in addition to the demographic shrinking of the last decade, the overcounting of 2010 would have to be deducted). Such a sharp reduction in the number of Russians in the republic could be negatively perceived 
not only in society, but also in the structures of the federal government, which is likely to force the republic's leadership not to take the risk and to resort to more overcounting.

Calculations of the likely dynamics of the Russian population of Karachaevo-Cherkessia for the medium and longer term lead to a mid-century demographic corridor in the range of 70100 thousand people. The upper limit would result from a positive scenario of natural dynamics and an outflow at the annual level of $0.3 \%$ of the local Russian population, while the lower one would result from a negative natural dynamics and migration at the level of $0.8 \%$ per year.

It is also necessary to take into account the deformation of the sex and age composition. As in other republics, Russian migration from Karachaevo-Cherkessia consists mainly of young people. So, already in the second half of the $21^{\text {st }}$ century the local Russian community, by critically increasing the proportion of the elderly population, could increase several times over the rate of its natural decline and within one or two decades become a candidate for compression under the Dagestan scenario.

\section{ADYGEA}

Adygea is the only republic in the North Caucasus where Russians continue to be the main ethnic group. It is significant that even in the 1990s, characterized by a surge of local nationalism, Adygea remained attractive to Russian migration from other regions of the Russian Federation. During the period 1989-2002 the number of Russians in the republic decreased from 297,000 to 289,000, while their natural loss came to about 15-16 thousand people at that time. Thus, about half of the losses were compensated by the migration inflow.

Also minimal were the practical results of the republic's migration policy aimed at bringing back the descendants of the $19^{\text {th }}$ century Circassian Muhajirs. It is significant that even the Syrian Circassians, forced to leave their war-torn country, were for the most part sent to Europe and Turkey. The total number of foreign Circassians returning to the North Caucasus during the postSoviet period (i.e., over a quarter of a century) was several thousand people, of which only a part returned to Adygea.

The "joining" of the republic to Krasnodar Krai (one of the main centers of attraction of immigrants from all over the Russian Federation) determined the positive migration balance of Adygea in the 2000s. Inflow exceeded 10,000 people, a significant part of whom were Russian.

This replenishment was supposed to make up for half of the demographic losses from the natural decline of the republic's Russians, which for the period 2002-2010 was about 11-12 thousand people. But in this case, the total number of Russians in Adygea should have shrunk over the intercensal period from 288,000 to 282-283 thousand. However, the 2010 census recorded a population of only 271,000 Russians in the republic, as if its natural loss had been supplemented by an outflow, which obviously does not correspond to migration statistics.

But even if we assume that the influx of Russians into the republic in the next few decades will be replaced by an outflow and that this trend will become stable, the very scale of the demographic importance of Adygea's Russians is a reliable guarantee of their remaining the most numerous ethnic group in the region for a long time to come (Figure 10). 


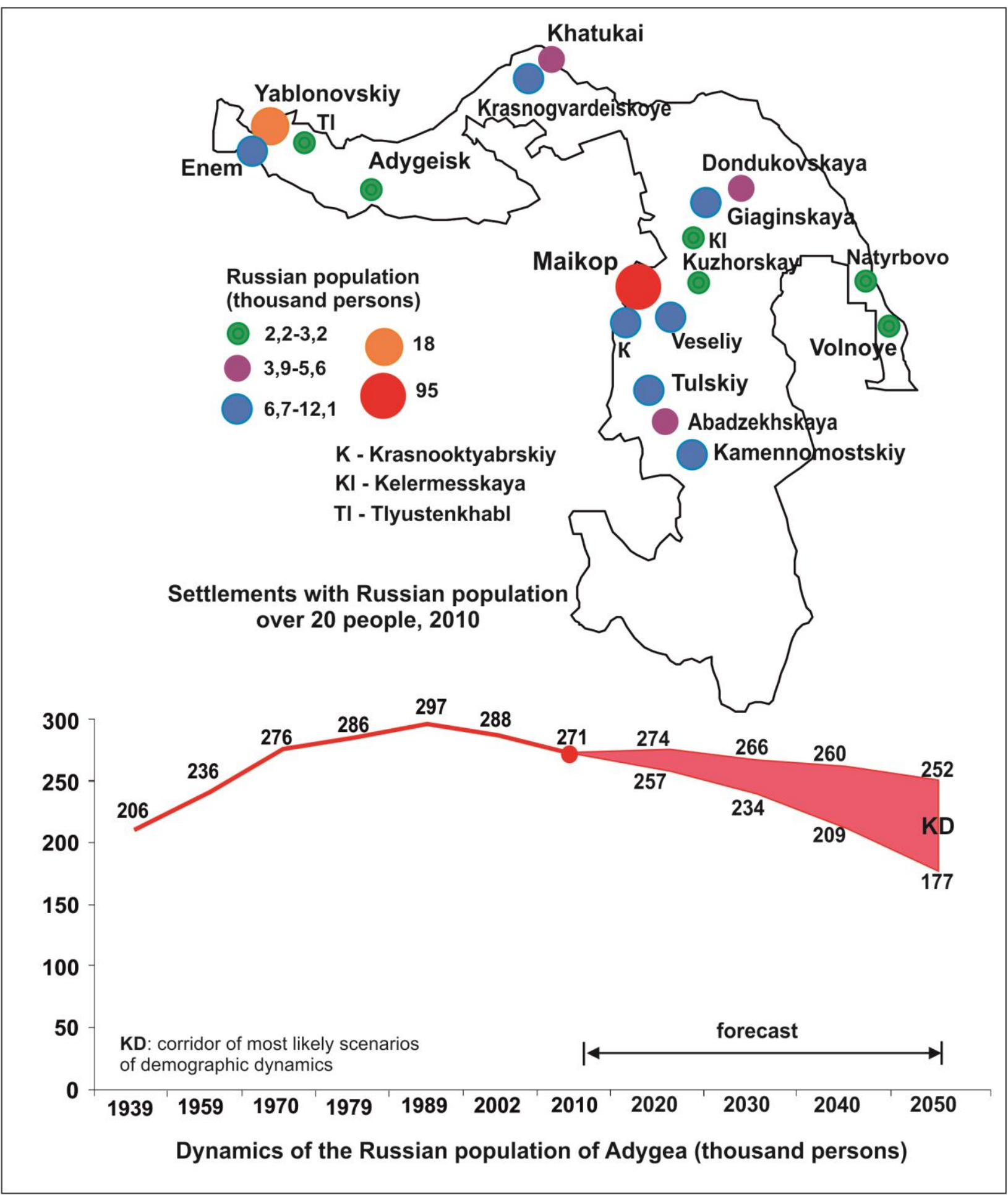

Figure 10. Russians in Adygea, 1939-2050

With an annual outflow of $0.3 \%$ and a negative scenario of natural dynamics, the number of Russians in the republic by the middle of the century may drop below 180,000 people, yet it will still be 1.5-1.6 times higher than the number of Adygeans. But Adygea, let's repeat, is an exception among all the region's republics. 


\section{CONCLUSIONS}

The decline of the Russian population in the republics of the North Caucasus, which began in the 1970s, has now developed into a stable trend. Given the existing ethno-political, socio-economic and socio-cultural realities, stopping it appears impossible. The only question is whether it can be minimized by reducing the scale of the migration outflow of Russians. But even such a compromise solution of the "Russian question" in fact presupposes a fairly serious modernization of the North Caucasus consistently implemented by the federal center, which also seems extremely unlikely, given the peculiarities of the ethnic policy of the current Russian government and its very limited capabilities for long-term planning.

This means that the process of the natural decline of Russians in the North Caucasus, characteristic of the entire Russian Federation, will be substantially supplemented and accelerated by migration outflow from the republics. It is migration in the next 2-3 decades that will continue as the central mechanism for the accelerated reduction of the Russian demographic presence in the republics of the region. At the same time, not only the quantitative scale of the outflow, but also the deterioration in the age structure of the remaining Russians (the bulk of migrants are people aged 20-40 years) are of great importance.

The role of the migration factor will begin to grow rapidly by the middle of the century, when in the group of pensioners there may already be about 30-40\% of the entire Russian population of the republics of the North Caucasus, and thus it will enter a period of intensive and, some time later, possibly catastrophic shrinkage.

However, the natural losses of Russians will begin to grow significantly in the near future, since the progressive reduction in the number of Russian women of reproductive age in all republics (as well as in the Russian Federation as a whole) has already begun, and by 2030 their number will be reduced by $25-30 \%$ of the 2010 level.

In other words, the shrinking of the Russian population of the North Caucasus is inevitable; the only question is how it will play out. At present, its size has already dropped to the level of the mid-1930s. By 2030, under a negative demographic scenario, there may remain fewer than 700,000 Russians in the region, and by the middle of the $21^{\text {st }}$ century, fewer than 500,000 (Figure 11). However, a positive scenario is also possible, in which the demographic losses will be considerably smaller and the number of Russians will fall by no less than 700,000 by 2050 . 


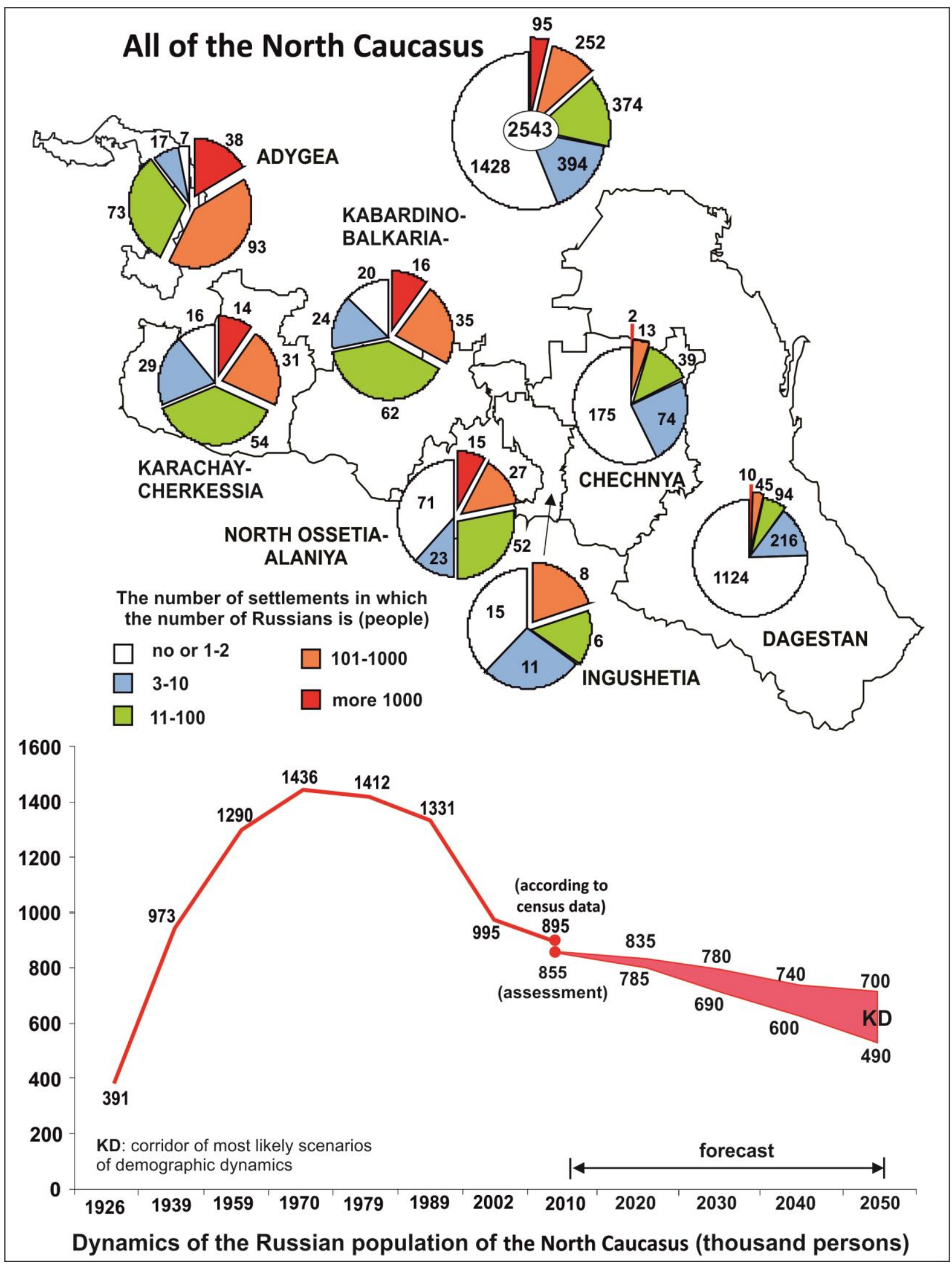

Figure 11. Russians in the North Caucasus, 1926-2050

Almost inevitable too is the further reduction of the "geographical" representation of Russians. Already at present, out of 2,500 settlements in the North Caucasus, more than $56 \%$ are practically lacking a Russian population, and only in 358 (14\%) of them are there territorial groups of more than 100 people. Obviously, over time, the number of settlements without a Russian 
population will increase (primarily due to small settlements). At the same time, the specific ratio of different subregions of the North Caucasus will change. While in the middle of the $20^{\text {th }}$ century almost $44 \%$ of the Russian population of the republics lived in the east of the national region, at present the share of the three eastern national autonomies has fallen below 14\%, and by the middle of the century is likely to drop to $11-12.5 \%$. In the central part of the North Caucasus the share of Russians will decrease from 54.6 to $51.4-52.8 \%$ (Figure 12), while in the western subregion (Adygeya) it will grow to $36 \%$.

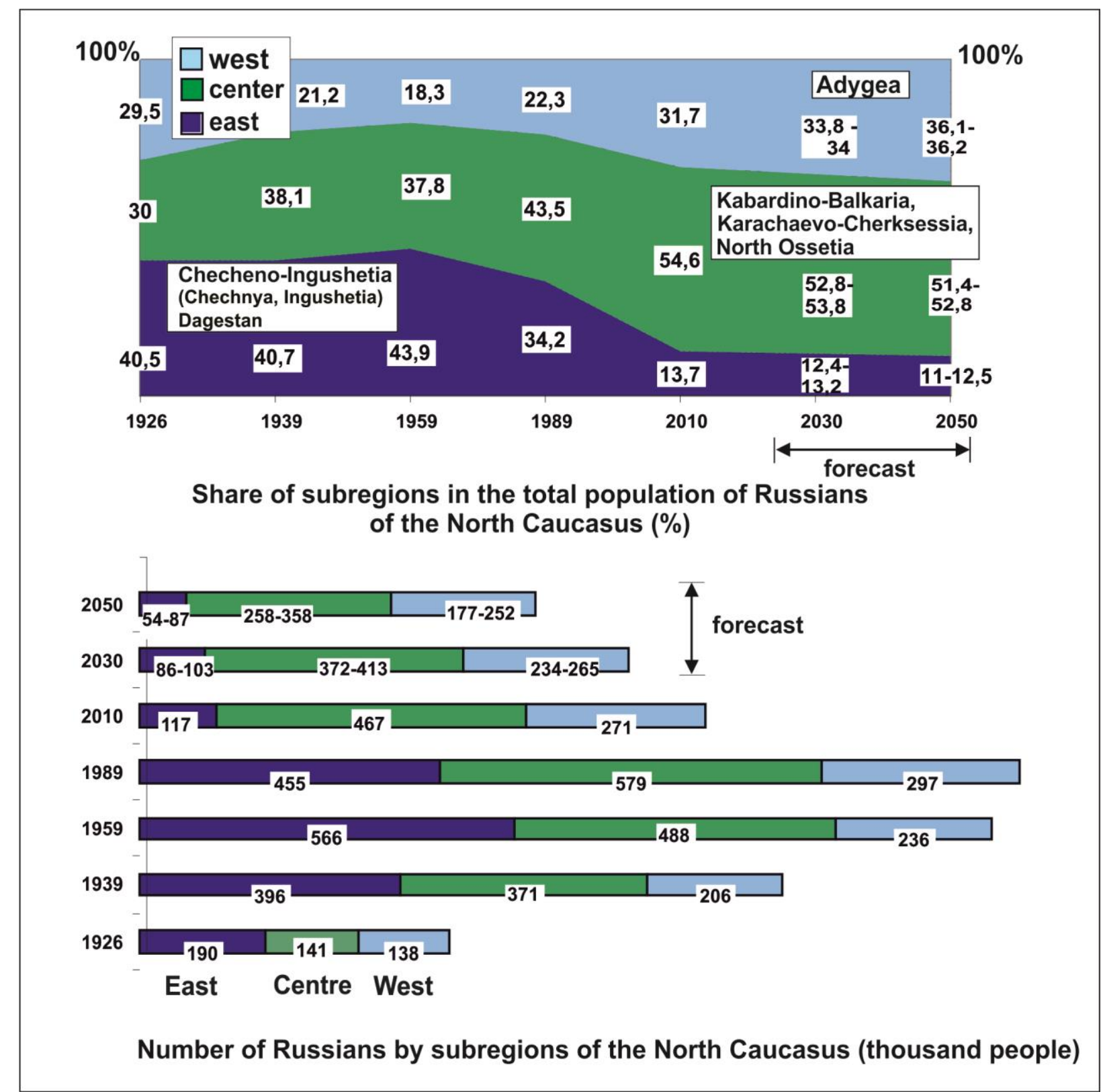

Figure 12. Russian population in the subregions of the North Caucasus, 1926-2050, \%, thousand people

However, it should be understood that the horizon of our research is limited to the mid- $21^{\text {st }}$ century. Until that time, the probability of a sharp reduction in the number of Russians is small. But the very stability of natural decline and migration outflow, together with negative shifts in the age and sex composition, significantly increases the likelihood of the demographic collapse of the republics' Russians in the second half of the century. And it doesn't matter whether this will take 
place in the century's third or fourth quarter. Whether 20-30 years earlier or later, the median age of the Russian population of the North Caucasus could exceed 50 years, and from that time on its demographic contraction will begin to acquire an irreversible and self-accelerating character.

\section{REFERENCES}

Ataev A.V. (2013). Status i perspektivy russkogo naseleniya na Severnom Kavkaze [Status and prospects of the Russian population in the North Caucasus]. URL: https://riss.ru/smi/3863/ (accessed: 14.02.2017).

Belozerov V. S. (2001). Russkie na Severnom Kavkaze: evolyutsiya rasseleniya [Russian North Caucasus: the evolution of settlement] // Russkie na Severnom Kavkaze: vyzovy XXI veka [Russian North Caucasus: challenges of the XXI century]. Rostov-na-Donu: IPPK RGU i ISPI RAN: 58-70.

Dagestan-2005: Sotsial'no-ekonomicheskoe polozhenie [Dagestan-2005: Socio-economic status] (2006). Makhachkala: Komitet po statistke RD. 244 p.

Denisova G.S., V.P. Ulanov (2003). Russkie na Severnom Kavkaze: analiz transformatsii sotsiokul'turnogo statusa [Russians on Northern Caucasus: analysis of transformation of socio-cultural status]. Rostov-na-Donu: Izdatel'stvo RGPU. 352 p.

Dzadziev A. B. (2007). Sovremennaya etnograficheskaya situatsiya [Modern ethnographic situation] // Byulleten' seti etnologicheskogo monitoringa i rannego preduprezhdeniya konfliktov [Bulletin of the network of ethnological monitoring and early conflict prevention]. 74 (iyul'-avgust) [74, July-August]. Moscow: 56-59.

Dzadziev A.B. (2008). Russkoe naselenie respublik Severnogo Kavkaza: sovremennye migratsionnye ustanovki [Russian population of the North Caucasus: current migration installation] // Severnyy Kavkaz v natsional'noy strategii Rossii [Northern Caucasus in the national strategy of Russia]. Moscow: Rosinformagrotekh: 129-148.

Kabuzan V.M. (1996). Naselenie Severnogo Kavkaza v XIKh-KhKh vekakh [The population of the North Caucasus in the XIX-XX centuries]. St. Petersburg: Blits. 224 p.

Severnyy Kavkaz: russkiy faktor [The North Caucasus: Russian factor] (2010). Ekspertnyy doklad [Expert report]. URL: http://www.rus-obr.ru/l 